\title{
Spatiotemporal Sediment Nutrient Dynamics of Kware Lake, Nigeria
}

\author{
Ibrahim Muh'd Magami ${ }^{1}$, Ibrahim Sani ${ }^{2}$ \\ ${ }^{1}$ Usmanu Danfodiyo University \\ P. M. B. 2346, Sokoto, Nigeria \\ ${ }^{2}$ Bayero University Kano \\ Nigeria Gwarzo Road, P. M. B. 3011, Kano, Nigeria
}

DOl: $10.22178 /$ pos. $45-2$

LCC Subject Category: QH1-(199.5)

Received 26.03.2018

Accepted 27.04.2019

Published online 30.04.2019

Corresponding Author:

Ibrahim Magami

ibrahim.magami@udusok.edu.ng

(c) 2019 The Authors. This article

is licensed under a Creative Commons

Attribution 4.0 License @) (1)

\begin{abstract}
Kware Lake provides life to various forms of aqua flora and fauna, livelihood for fishermen community and food for the local populace. The study was conducted to evaluate nutrient dynamics of the lake's sediment for a period of 12 months (June 2014 to May 2015). Results reveal that some of the variables studied did not show any variation due to space and time but electrical conductivity (EC), phosphate (P043-), potassium, sodium and clay texture were able to vary according to months, seasons and stations. They recorded range of $101.3-113 \mu \mathrm{s} / \mathrm{cm}, 0.97-1.24 \mathrm{~g} / \mathrm{Kg}, 0.29-0.37 \mathrm{~g} / \mathrm{kg}, 0.62-0.77 \mathrm{~g} / \mathrm{kg}$, and 13$14 \mathrm{~g} / \mathrm{kg}$ respectively. Results therefore suggest and confirmed that sediment has a high accumulation of phosphate, due to decomposition on the sediment bed and low nitrate level in sediment than in surface water.
\end{abstract}

Keywords: Kware; seasons; sediment; spatiotemporal; stations; variables.

\section{INTRODUCTION}

Sediment plays an important role in the overall nutrient dynamics of shallow lakes. Nutrients dynamics is usually influenced by the biological structure in the pelagic zone, and lakes shifting from turbid to clear water [1]. Nutrients in sediment are chemicals essential for primary production in water bodies; their sources include regeneration from the decomposition of aquatic plants, substrates, mixing processes between the sediments and the overlying waters, terrestrial sources such as domestic sewage, and fertilizer from leached soils or precipitation of particulate matter [2, 3]. Movement of nutrients from the sediment column to the water column is an important process whose significance depends upon the efficiency of the mixing mechanism [3]. Nitrogen and phosphorus may be limiting factors for primary production in lakes and they occur in different forms. Phosphorus occurs mainly as orthophosphate while nitrogen occurs mainly as nitrate, nitrite, and ammonia, their concentration usually influence the availability of food to aquatic biota [3]. The biological structure of a lake can significantly boost its phosphorus concentrations and retention [4]. It has been re- ported that phosphorus availability is regarded as the most important factor for determining the water quality of lakes. Numerous studies have shown that high phosphorus load leads to high phytoplankton biomass, while turbid water can lead to undesired biological changes. The latter include; loss of biodiversity, the disappearance of submerged macrophytes, fish stock changes, and decreasing top-down control by zooplankton on phytoplankton [1].

Higher loading of bioavailable phosphate to the lake leads to enhanced primary production in the lake and thereby larger inputs of organic material to the sediments. This increases the mineralization and thereby oxygen consumption, which subsequently leads to increased phosphate release from sediments [5].

Bottom sediments in natural systems are formed by the sedimentation process. Due to digenetic processes such as precipitation, adsorption, reduction, remobilization, biological degradation, and biological uptake, the concentrations of nutrients in the pore water are higher than the overlying water $[1,6]$. Most of the nutrients and chemicals under normal circumstances tend to accumulate in the sediments, which later settle 
down at the lake bed. Lake sediments can act both as sources and sinks for phosphate relative to the overlying lake waters, depending on the $\mathrm{pH}$ conditions and sedimentary iron concentrations and organic matter degradation [1]. Organic degradation is a result of microbial activity. This results in a release of phosphate in the pore waters [6]. Nutrient concentrations in sediment have so far received very little attention in Nigerian lakes. This study was conducted to assess the nutrients level in the sediment of Kware Lake, with the view of providing baseline information on the nutrients load of the lake sediments.

\section{MATERIALS AND METHODS}

Kware lake is a naturally occurring freshwater, located at Kware Local Government Area of Sokoto State, about $20 \mathrm{~km}$ northeast of Sokoto metropolis. It is located on longitude $5^{\circ} 16^{\prime} \mathrm{N}$ and latitude $13^{\circ} 15^{\prime} \mathrm{E}$. Kware is flanked by Shella to the northeast and River Rima to the east. The vegetation of the area is Sudan savannah, mostly dominated by grasses, and small trees. It is characterized by two distinct seasons, the short raining season which runs from May to September / October depending on the rainfall pattern of the year. The long dry season occurs from October / November to April. The humidity is less than $20 \%$ and a temperature range from $27^{\circ} \mathrm{C}$ to $42^{\circ} \mathrm{C}$ (Figure 1).

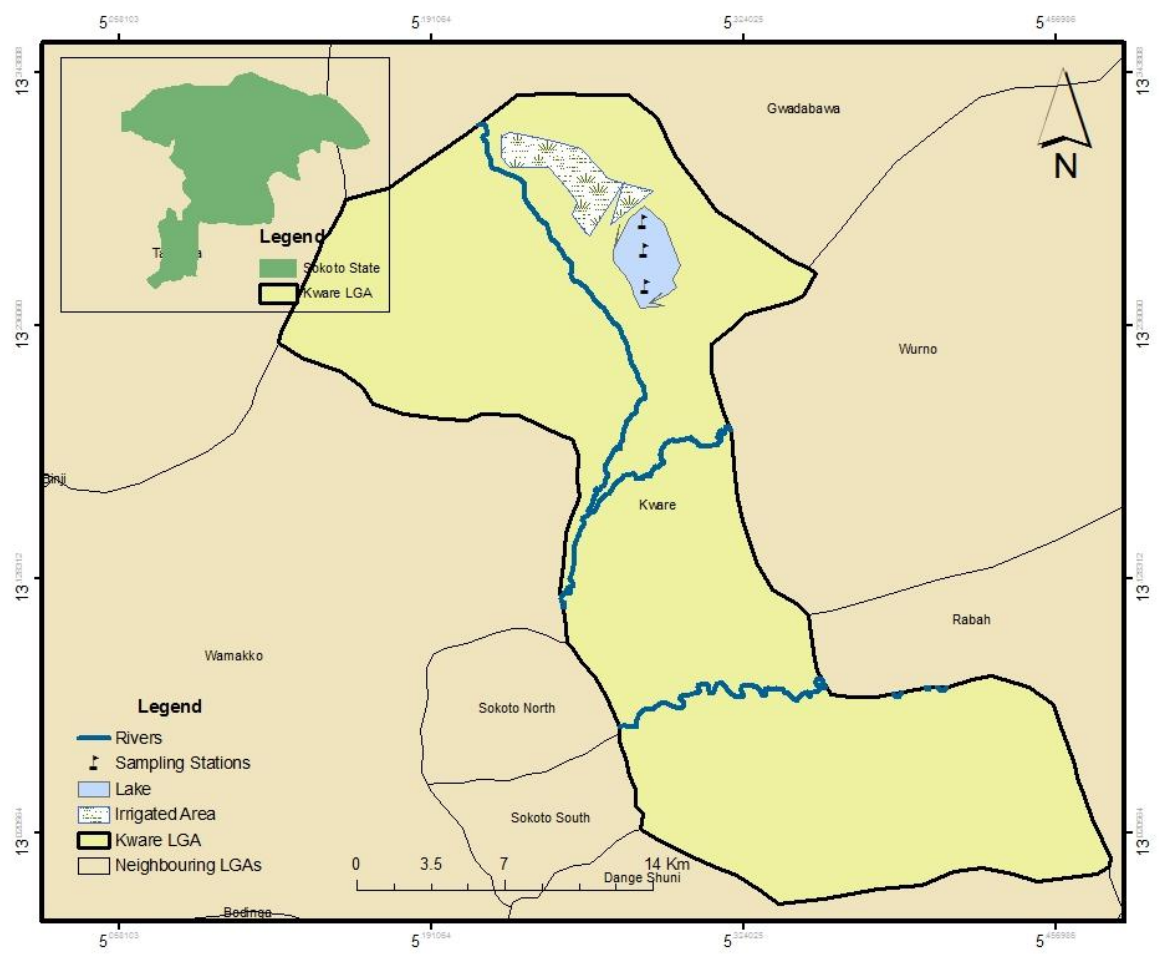

Figure 1 - Map of the Study Area Showing Kware Lake [7]
Sediment core was collected from June 2014 to May 2015, in sterilized polythene bags from three locations designed for the study. These were oven dried before determination of chemical variables [8].

Chemical variables were determined according to standard methods, these include; pH, EC organic carbon, nitrate, phosphorus, calcium, magnesium and sodium. Phosphorus was determined using spectrophotometer (JENWAY 6100) at $660 \mathrm{~nm}$ (wavelength); potassium and sodium were determined using flame photometer (Corning 400 Essex, England), while magnesium and calcium were determined using ethylenediamine tetraacetic acid (EDTA) titration method. Organic carbon was determined by quantitative dry combustion procedures [9]. Soil texture (sand, silt, and clay) were determined using hydrometer as described by [10]. Hydrogen ions (pH), EC, nitrate, phosphorus, calcium, magnesium, sodium, potassium were determined with standard procedures $[9,11,12]$.

Data obtained were subjected to statistical analysis; analysis of variance (ANOVA) was adopted, significant difference probability at $\mathrm{P}<0.05$ was accepted [13]. 


\section{RESULTS AND DISCUSSION}

Geochemical analysis of sediment provides information for changes in environmental conditions, within and around a lake. Phosphate, nitrate and organic carbon are a good indicator of total organic matter within the sediment and a useful proxy for biomass production of a water body [14]. This study revealed high availability of phosphate, which was lower than nitrate, $\mathrm{pH}$ was acidic throughout the year of study (June 2014 to May 2015), with a mean range of 6.57-7.03 which indicated the lake was still within the acidic level (Table 1).

The significant difference between both months and seasons observed was due to slight fluctuations of $\mathrm{pH}$ between months (Table 2).

Table 1 - Sediment Physicochemical Variables June 2014-May 2015 of Kware Lake, Nigeria

\begin{tabular}{|l|c|c|c|c|c|c|c|}
\hline Months & $\mathrm{pH}$ & $\mathrm{EC}(\mu \mathrm{s} / \mathrm{cm})$ & $\mathrm{OC}(\mathrm{g} / \mathrm{Kg})$ & $\mathrm{Ca}(\mathrm{g} / \mathrm{Kg})$ & $\mathrm{Mg}(\mathrm{g} / \mathrm{Kg})$ & $\mathrm{K}(\mathrm{g} / \mathrm{Kg})$ & $\mathrm{Na}(\mathrm{g} / \mathrm{Kg})$ \\
\hline Jun. & $6.60 \pm 0.10$ & $109.7 \pm 0.66$ & $6.13 \pm 0.22$ & $1.28 \pm 0.05$ & $1.23 \pm 0.03$ & $0.36 \pm 0.02$ & $0.75 \pm 0.01$ \\
\hline Jul. & $7.00 \pm 0.00$ & $101.3 \pm 0.33$ & $3.10 \pm 0.15$ & $1.14 \pm 0.15$ & $1.31 \pm 0.01$ & $0.37 \pm 0.00$ & $0.64 \pm 0.01$ \\
\hline Aug. & $7.03 \pm 0.23$ & $110.3 \pm 1.20$ & $6.73 \pm 0.17$ & $1.33 \pm 0.02$ & $1.27 \pm 0.04$ & $0.37 \pm 0.02$ & $0.72 \pm 0.04$ \\
\hline Sep. & $6.57 \pm 0.07$ & $110.0 \pm 1.53$ & $6.10 \pm 0.20$ & $1.21 \pm 0.10$ & $1.23 \pm 0.02$ & $0.35 \pm 0.03$ & $0.73 \pm 0.02$ \\
\hline Oct. & $6.80 \pm 0.12$ & $110.3 \pm 1.33$ & $5.17 \pm 0.07$ & $1.19 \pm 0.10$ & $1.18 \pm 0.10$ & $0.32 \pm 0.02$ & $0.62 \pm 0.01$ \\
\hline Nov. & $6.70 \pm 0.12$ & $113.0 \pm 0.56$ & $5.83 \pm 0.22$ & $1.15 \pm 0.09$ & $0.92 \pm 0.28$ & $0.32 \pm 0.02$ & $0.71 \pm 0.01$ \\
\hline Dec. & $6.73 \pm 0.09$ & $109.0 \pm 1.73$ & $6.47 \pm 0.12$ & $1.25 \pm 0.09$ & $1.23 \pm 0.02$ & $0.35 \pm 0.02$ & $0.77 \pm 0.01$ \\
\hline Jan. & $7.00 \pm 0.06$ & $111.0 \pm 2.00$ & $6.03 \pm 0.26$ & $1.16 \pm 0.09$ & $1.23 \pm 0.01$ & $0.33 \pm 0.02$ & $0.71 \pm 0.01$ \\
\hline Feb. & $6.87 \pm 0.12$ & $111.0 \pm 0.58$ & $6.06 \pm 0.27$ & $1.16 \pm 0.09$ & $1.11 \pm 0.00$ & $0.29 \pm 0.00$ & $0.71 \pm 0.01$ \\
\hline Mar. & $7.00 \pm 0.06$ & $112.0 \pm 0.58$ & $6.10 \pm 0.06$ & $1.17 \pm 0.04$ & $1.11 \pm 0.00$ & $0.30 \pm 0.01$ & $0.72 \pm 0.00$ \\
\hline Apr. & $6.97 \pm 0.03$ & $111.3 \pm 0.33$ & $6.13 \pm 0.03$ & $1.13 \pm 0.08$ & $1.12 \pm 0.06$ & $0.31 \pm 0.00$ & $0.72 \pm 0.00$ \\
\hline May. & $6.97 \pm 0.03$ & $110.7 \pm 0.67$ & $6.03 \pm 0.09$ & $1.15 \pm 0.06$ & $1.13 \pm 0.06$ & $0.31 \pm 0.01$ & $0.72 \pm 0.01$ \\
\hline Range & $6.57-7.03$ & $101.3-113$ & $3.1-6.73$ & $1.13-1.33$ & $0.92-1.31$ & $0.29-0.37$ & $0.62-0.77$ \\
\hline
\end{tabular}

Table 2 - Statistical Summary for Physicochemical Variables of Kware Lake, Nigeria

\begin{tabular}{|l|r|r|r|r|r|r|}
\hline \multicolumn{1}{|c|}{ Sources of Variation $\rightarrow$} & \multicolumn{2}{c|}{ Season } & \multicolumn{2}{c|}{ Monthly } & \multicolumn{2}{c|}{ Stations } \\
\hline Variables & F-Value & P-Value & F-Value & P-Value & F-Value & P-Value \\
\hline $\mathrm{pH}$ & $2.2961>$ & 0.1606 & $2.6690>$ & 0.0214 & $0.1533<$ & 0.8584 \\
\hline $\mathrm{EC}(\mu \mathrm{s} / \mathrm{cm})$ & $1.0498>$ & 0.3296 & $6.9662>$ & 3.7934 & $1.2710>$ & 0.2939 \\
\hline $\mathrm{OC}(\mathrm{g} / \mathrm{Kg})$ & $1.3997>$ & 0.2641 & $29.1883>$ & 3.2470 & $0.3485<$ & 0.7082 \\
\hline $\left.\mathrm{NO}_{3}-\mathrm{g} / \mathrm{Kg}\right)$ & $0.1050<$ & 0.7525 & $18.0262>$ & 5.3463 & $0.1771<$ & 0.8384 \\
\hline $\mathrm{PO}_{4}{ }^{-3}(\mathrm{~g} / \mathrm{Kg})$ & $1.7791>$ & 0.2118 & $2.5815>$ & 0.0252 & $1.2507>$ & 0.2995 \\
\hline $\mathrm{Ca}(\mathrm{g} / \mathrm{Kg})$ & $1.8523>$ & 0.2033 & $0.5224<$ & 0.8690 & $11.8750>$ & 0.0001 \\
\hline $\mathrm{Mg}(\mathrm{g} / \mathrm{Kg})$ & $0.0336<$ & 0.8581 & $1.2155>$ & 0.3292 & $1.5830>$ & 0.2205 \\
\hline $\mathrm{K}(\mathrm{g} / \mathrm{Kg})$ & $5.6416>$ & 0.0389 & $2.1846>$ & 0.0530 & $6.0806>$ & 0.0056 \\
\hline $\mathrm{Na}(\mathrm{g} / \mathrm{Kg})$ & $1.7846>$ & 0.2111 & $8.6753>$ & 5.8991 & $0.9765>$ & 0.3872 \\
\hline Sand $(\mathrm{g} / \mathrm{Kg})$ & $0.1689<$ & 0.6897 & $0.0755<$ & 0.9999 & $77.2230>$ & 3.5730 \\
\hline Silt $(\mathrm{g} / \mathrm{Kg})$ & $0.1357<$ & 0.7202 & $0.3617<$ & 0.9590 & $49.6670>$ & 1.1165 \\
\hline Clay $(\mathrm{g} / \mathrm{Kg})$ & $0.5555>$ & 0.4732 & $1.0363>$ & 0.4471 & $1.4172>$ & 0.2567 \\
\hline
\end{tabular}

Notes: F-value: represent calculated value, P-value: represent tabulated value. Where ever F-value is presented with $>$ (greater sign) means there was significant difference for the variable. While the < (less sign) means no significant difference at $(P<0.05)$.

Life and growth of plants are directly affected by $\mathrm{pH}$ which consequently affects the availability of plant nutrients, $\mathrm{pH}$ above 6.5 in the present study indicated nutrients were possibly found to be in solution due to favorable $\mathrm{pH}$ conditions of the water $\mathrm{pH}>6.5[15]$.
Electric conductivity (EC) measurement was uniform from August to October 2014 but tends to increase slightly from December and becomes stable from January to March. The EC, therefore, reveals that difference exists between all the sources of variation evaluated in this study; months, seasons and stations (Tables 1-2). 
Organic carbon content varied during this study, but the variation was more observed in 2014 (June to December) while in 2015 the means we're more or less uniform (Table 1) and Fvalues and P-values (1.3997>0.2641), $(29.1883>3.2470)$ and $(0.3485<0.7082)$ for seasons, months and stations respectively (Table 2). This indicated no significant difference $(p<0.05)$ between the stations on organic carbon content and least mean (3.10 \pm 0.15$)$ was obtained in July. This indicated a fluctuation throughout the study period, which has been reported to be an important consideration when assessing the biogeochemical status of lakes [16].

Calcium level in the sediment was higher in June $(1.28 \mathrm{~g} / \mathrm{kg})$ and also in December $(1.25 \mathrm{~g} / \mathrm{kg})$. The lowest calcium concentration observed during the study $(1.13 \mathrm{~g} / \mathrm{kg})$ although there was no significant difference between the months $(\mathrm{P}<0.05)$.

Similarly, the magnesium concentration in the sediment did not show any variation between months although it was observed to be significant between the seasons and stations $(\mathrm{P}<0.05)$. Potassium level was lowest than all other nutrients studied. Though, potassium was more or less uniform throughout the year. The level of sodium was higher than potassium but lower than magnesium and calcium (Table 1). Though, monthly values recorded indicated a slight fluctuation with a range of $0.62-0.75 \mathrm{~g} / \mathrm{kg}$ in which the minimum $(0.62 \mathrm{~g} / \mathrm{kg})$ was found in October.

Phosphate and nitrate have been reported to influence the growth of aquatic organisms, which consequently contribute to their abundance [17]. Level of phosphate in the present study was higher than the level of nitrate (Figure 2).



Figure 2- Monthly Concentration of Phospahte and Nitrate from June 2014 to May 2015 in Kware Lake, Nigeria

July was observed to have the highest phosphate level; this may likely be due to the initial rainfalls that introduced fertilizer, insecticides, pesticides used at the catchment farmlands. While nitrate was lowest in December. Phosphate was generally twice higher than the nitrate; which agrees with [8], where phosphate accumulation was 1.5 to 3 times higher than nitrate. The high level of phosphorus in the sediment than nitrate may likely be due to decomposed organic matter which is permanently fixed in the sediment or recycles back in overlying water as available nutrients as an analogy to nitrogen on the surface water [17].
Soil texture in the present study is the only variable that was more or less stable spatiotemporally, most likely due to immobility of the variable, contrary to other physicochemical properties that could change due to space and time (Figure 3). The results suggest an abundance of sand texture than silt and clay tends to be the limiting soil texture in the sediment, most likely because Sokoto is semi-arid with sand as the dominant soil type [18]. Though, phosphate concentration is usually known to be controlled by the percentage of the clay minerals in sediment due to their large surface area $[1,19]$. 


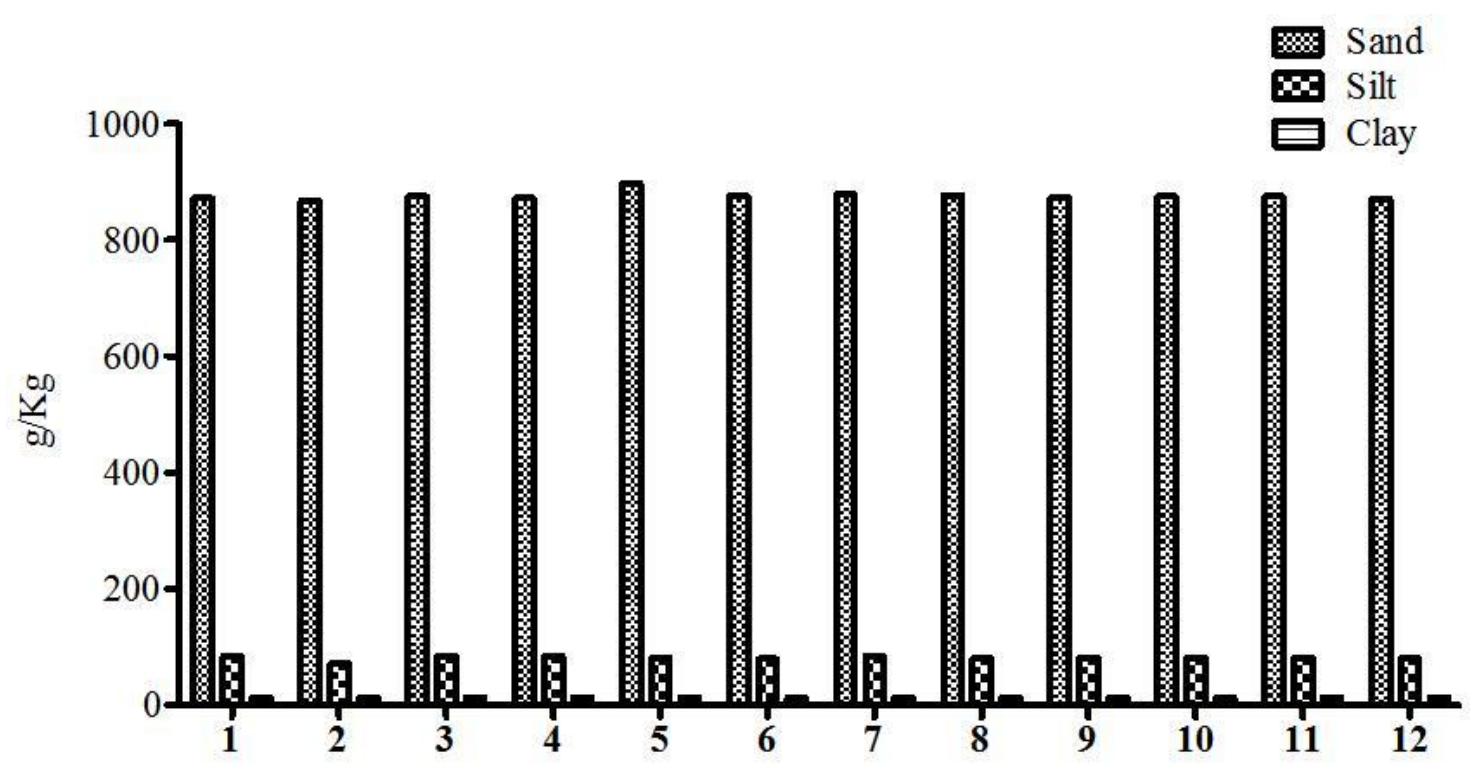

Figure 3- Soil Texture from June 2014 to May 2015 of in Kware Lake, Nigeria

Low level of clay in the soil texture of Kware Lake was in line with the findings [20], who conducted a similar study in a eutrophic lake.

\section{CONCLUSION}

Kware Lake sediment varied spatiotemporally, with some of the variables indicating no relation with space and time. The major growth nutrients (phosphorus and nitrogen) have also revealed to be available for the growth of aquatic biota, but phosphate tends to be higher in the than the nitrate.

\section{REFERENCES}

1. Søndergaard, M., Jensen, J. P., \& Jeppesen, E. (2003). Role of Sediment and Internal Loading of Phosphorus in Shallow Lakes. Hydrobiologia, 1, 135-145.

2. Wetzel, R. G. (2001). Limnology. Lake and River Ecosystems (3rd ed.). London: Academic Press.

3. Coulter, G. W. (1991). Lake Tanganyika and its Life. Oxford: Oxford University Press.

4. Beklioglu, M., Carvalho, L., Moss, B. (1999). Rapid Recovery of a Shallow Hypertrophic Lake Following Sewage Effluent Diversion: Lack of Chemical Resilience. Hydrobiologia, 4(12), 5-15.

5. Jensen, H. S., \& Andersen, F. O. (1992). Importance of temperature, nitrate, and pH for phosphate release from aerobic sediments of four shallow, eutrophic lakes. Limnology and Oceanography, 37(3), 577-589. doi: 10.4319/lo.1992.37.3.0577

6. Cohen, A. (2003). Paleolimnology: The History and Evolution of Lake Systems. Oxford: Oxford University Press.

7. Muhammad, Z. (2011). Assessment productivity status of Kware Lake (Undergraduate Project), Sokoto, Usmanu Danfodiyo University. N. d.: n.d.

8. Craft, B. C., Casey, W. P. (2000). Sediment and nutrient accumulation in floodplain and depressional freshwater wetlands of Georgia, USA. Wetlands, 20(2), 323-332.

9. Latimer, G. (2019). Official Method of Analysis of AOAC International (21st ed.). Washington: AOAC.

10. Nollet, L. (Ed.). (2007). Handbook of Water Analysis (2nd ed.). London: CRC Press. 
11. Hack, B. (2000). Analytical Method of Determination of Mineral Nutrients. In Dolphin, \& S. John (Eds.), Text on Analytical in Practice (pp. 26-33). New York: New York In. Press.

12. United Nations Environment Programme. (2014). Analytical Methods for Environmental Water Quality. Retrieved from https://www.waterandchange.org/wpcontent/uploads/2016/08/Analytical-Methods-GEMS-2014.pdf

13. Motulsky, H. J. (2007). Prism 5 Statistics Guide. San Diego: GraphPad.

14. Burgess, H. D. (2007). Geochemical Indicators of Productivity Change in Lake Champlain, USACanada (Master's Thesis), Faculty of the Graduate College, University of Vermont, USA.

15. Vossen, P. (n. d.). Changing pH in Soil. Retrieved March 1, 2019, from https://vric.ucdavis.edu/pdf/soil/ChangingpHinSoil.pdf

16. Wilson, R. F., Fennel, K., \& Paul Mattern, J. (2013). Simulating sediment-water exchange of nutrients and oxygen: A comparative assessment of models against mesocosm observations. Continental Shelf Research, 63, 69-84. doi: 10.1016/j.csr.2013.05.003

17. Goldeman, C. R., Horne, A. J. (1994). Limnology. London: McGraw-Hill International Book Co.

18. Ita, E. O., Balogun, J. K., \& Ademola, A. (1982). A Preliminary Report of Pre-impoundment Fisheries Study of Goronyo Reservior, Sokoto State, Nigeria. N. d.: n. d.

19. Gächter, R., \& Müller, B. (2003). Why the phosphorus retention of lakes does not necessarily depend on the oxygen supply to their sediment surface. Limnology and Oceanography, 48(2), 929-933. doi: 10.4319/lo.2003.48.2.0929

20. Łukawska-Matuszewska, K., Vogt, R. D., \& Xie, R. (2013). Phosphorus pools and internal loading in a eutrophic lake with gradients in sediment geochemistry created by land use in the watershed. Hydrobiologia, 713(1), 183-197. doi: 10.1007/s10750-013-1506-9 